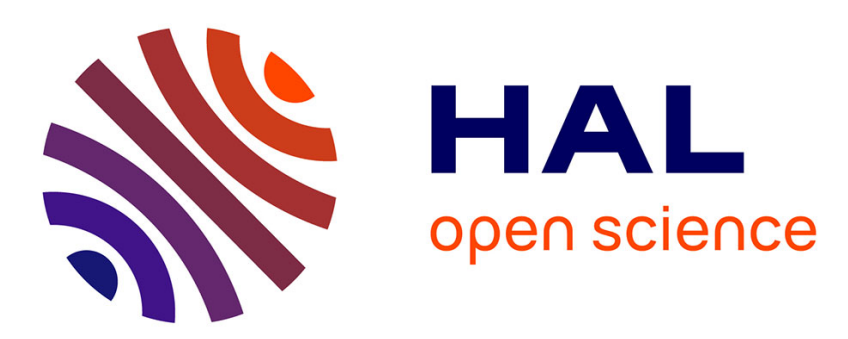

\title{
Decoupling and prices: determinant of dairy farmers' choices?
}

\author{
Baptiste Lelyon, Vincent Chatellier, Karine Daniel
}

\section{To cite this version:}

Baptiste Lelyon, Vincent Chatellier, Karine Daniel. Decoupling and prices: determinant of dairy farmers' choices?. Revue d'Etudes en Agriculture et Environnement - Review of agricultural and environmental studies, 2011, 92 (1), pp.47-68. hal-02641921

\section{HAL Id: hal-02641921 \\ https://hal.inrae.fr/hal-02641921}

Submitted on 28 May 2020

HAL is a multi-disciplinary open access archive for the deposit and dissemination of scientific research documents, whether they are published or not. The documents may come from teaching and research institutions in France or abroad, or from public or private research centers.
L'archive ouverte pluridisciplinaire HAL, est destinée au dépôt et à la diffusion de documents scientifiques de niveau recherche, publiés ou non, émanant des établissements d'enseignement et de recherche français ou étrangers, des laboratoires publics ou privés. 


\title{
Decoupling and prices: determinant of dairy farmers' choices?
}

\author{
Baptiste LELYON*, Vincent CHATELLIER**, Karine DANIEL*** \\ * Auteur correspondant : Institut de l'Elevage, Département Economie, 149 rue de Bercy, \\ 75595 Paris cedex 12 \\ e-mail : baptiste.lelyon@inst-elevage.asso.fr \\ ** INRA, UR1134, LERECO, rue de la Géraudière, 44316 Nantes \\ *** PRES LUNAM Université, ESA (Ecole Supérieure d'agriculture), LARESS, 55 rue Rabelais, \\ 49007 Angers, chercheur associé INRA, UR1134, LERECO, rue de la Géraudière, \\ 44316 Nantes
}

\begin{abstract}
Summary - In this paper, we discuss the cross-effects on the productive strategy of French dairy farms due to the decoupling and to price variation. A model based on mathematical programming has been developed to determine bow dairy farmers might re-evaluate their systems to identify an optimal production plan. The model is applied to four types of dairy farms in order to analyze the impact of the reform depending on farm's activities. The simulations point out bow the implementation of the decoupling encourages farmers to increase the share of grassland. However, the increase in cereal prices is a strong incentive to intensify forage production to free up land for crop production. Finally, after four years of decoupling, this study belps to put into perspective the theoretical effects of decoupling and the actual choices made by farmers. This article identifies six factors which could explain these differences: the longterm production requirements, the eligibility criteria for the direct payment, the sociology/psychology of the farmer, the anticipation of a new reform, the trade organization and the value of property assets.
\end{abstract}

Keywords: dairy farm, single payment, decoupling, price variation, mathematical programming, technical system

\section{Découplage et prix : les déterminants du choix des éleveurs ?}

Résumé - Dans cet article, nous discutons des effets croisés de la mise en œuvre du découplage et de la variation des prix sur les stratégies productives des exploitations laitières françaises. Un modèle basé sur la programmation mathématique a été construit afin de déterminer comment les producteurs de lait ré-évaluent leurs systèmes afin d'identifier le plan de production optimal. Ce modèle est appliqué à quatre types d'exploitations laitières afin de déterminer les impacts de la réforme sur différents systèmes techniques. Les simulations montrent que le découplage encourage les agriculteurs à modifier leurs assolements au profit d'une part croissante de prairies. Toutefois, l'augmentation du prix des céréales va dans le sens d'une intensification de la production fourragère permettant de libérer des surfaces pour les grandes cultures. Enfin, quatre années après l'application du découplage, cette étude permet de discuter de l'écart entre les effets théoriques attendus du découplage et les choix réellement opérés par les agriculteurs. Cet article identifie six facteurs pouvant expliquer ces différences : les caractéristiques d'une production agricole de long terme, les critères d'éligibilité au paiement direct, la psychologie/sociologie de l'agriculteur (aversion au risque), l'anticipation d'une nouvelle réforme, les organisations de commercialisation et la valeur des facteurs de production.

Mots-clés: production laitière, paiement unique, découplage, volatilité des prix, programmation mathématique, cas-types

JEL Classification: Q12, Q18, C61

\section{Acknowledgements}

We would like to thank the two anonymous reviewers and the participants at "12th Congress of the European Association of Agricultural Economists" (Ghent, August 2008) for valuable comments on earlier versions of this paper. This paper also benefited from comments by John Scott Shonkwiler visiting researchers INRA-Nantes. This research was funded by the research programs "Laitop" (PSDR Grand-Ouest) and "Dynamics of Dairy Territories in France and Europe" (funded by CNIEL, Crédit Agricole, FESIA, Groupama and SEPROMA). 


\section{Introduction}

Dairy farmers, in 2007, were facing an unprecedented situation on the markets with the soaring prices of agricultural raw materials. They then had to deal with the significant falls in those prices in the years 2008 and 2009 with, then again, a complete twist of situation in 2010. These fluctuations may lead them to change their system in order to adapt their production to this unstable economic situation. For French farmers, these changes occurred simultaneously with the implementation in 2006 of the reform of the Common Agricultural Policy (CAP). A key driver of this reform was the WTO Doha Round negotiations. Three innovations were introduced: i) the decoupling of direct support based, in France, on the amount of direct subsidies received in 2000-02 (historical approach); ii) the modification of the dairy Common Market Organisation: the intervention prices of industrial dairy products (butter and powder) were reduced, and subsidies were granted to farmers according to their dairy quota; iii) deduction of part of the direct subsidies from the first pillar of the CAP to fund the second pillar (modulation).

In this context, the aim of this paper is to study the behaviour of dairy farmers relating to the decoupling in a situation of strong price variations. A Mathematical Programming model is developed and applied to different French dairy farms. The model represents the behaviour of farmers who have optimized combination of production (both crops and animals) considering the price for inputs and outputs from the previous year, the amplitude of price variations and the modifications of the agricultural policy (decoupling) which can affect the profitability for some productions. The model incorporates the economic risk related to the variation of input and output prices by using the utility efficient programming method (monotonically increasing and concave objective function). The price variation is an important issue for farmers because the prices of agricultural commodities were subject to strong variations during the last years. For example the price of milk paid to the producer varied from $220 € / \mathrm{t}$ to $380 € / \mathrm{t}$ between 2007 and 2010. Prices for cereals such as wheat and maize followed the same evolution: from $110 € / t$ in the beginning of 2010 to $270 € / t$ just six months later.

This short-term model enables us to analyze, at a detailed level, the impacts of exogenous shock (policy modifications, input and output price variations) which can encourage farmers to change their productive strategy. Because of the diversity of technical systems in dairy farming, we consider four different types of farming according to the intensification of forage area and the level of specialization (grass based farm, semiintensive, milk + cereals, milk + young bull). In this way, we can identify whether farms have a different response to the decoupling and the price variation according to their technical practices. This model pays particular attention to the interactions between the feeding system and the management of land, and also to the farmer's sensitivity to price changes (risk aversion). Thanks to these specifications, the model offers a large choice of production combinations (specialization or diversification) and technical practices (level of intensification). 


\section{Materials and methods}

In order to study the adaptation of farmers' practices in response to the implementation of the decoupling, a mathematical programming model was built. This method allows us to identify the effects of the decoupling on the production system (i.e. the allocation of land areas to different crops, the level of intensification of these inputs). We can also study threshold effects and calculate dual values of inputs (shadow prices).

\subsection{Bio-economic model: a farm level approach}

Farm-level modelling enables simultaneous consideration of production, price and policy information. The model optimizes the farm plan, which represents the quantities of different outputs produced and inputs used. The economic results follow from those quantities and their prices. The model is used to estimate the effects of institutional, technical and price changes on the farm plan, economic results and intensification indicators. The model represents the operation of a dairy farm for a oneyear period but it is a static model, therefore there is no possibility of productive changes within the year.

Any model derived from mathematical optimization has three basic elements (Matthews et al., 2006): i) an objective function, which minimizes or maximizes a function of the set of activity levels; ii) a description of the activities within the system, with coefficients representing their productive responses; and iii) a set of constraints that define the operational conditions and the limits of the model and its activities. Given the objective function, the solution procedure determines the optimal solution considering all activities and restrictions simultaneously.

Many studies have demonstrated that farmers typically behave in a risk-averse way (Hardaker et al., 2004). Farmers often prefer productions providing a satisfactory level of security even if this means sacrificing some income. For the farmer, the main issue raised by variability of price and production is how to respond tactically and dynamically to opportunities or threats in order to generate additional income or to avoid losses. The volatility is a strong issue for farmers who had to face huge price variations for agricultural commodities from 2007 to 2010. Several methods exist to take into account the impact of price variation on the farmer productive behaviour. This model uses the utility efficient programming method (UEP) created by Lambert and McCarl (1985) and then reformulated by Patten et al. (1988). This approach, which does not require an assumption of normally distributed income (unlike the Esperance-Variance, the Minimization of Total Absolute Deviations (MOTAD) and Target MOTAD methods), can accommodate the assumption that the utility function is monotonically increasing and concave (risk-averse). The UEP method has a negative exponential utility function (with constant absolute risk aversion, CARA). Zuhair et al. (1992) show that this functional form can better predict farmers' behaviour than cubic and quadratic functions. The CARA function is a reasonable approximation to the real - but unknown - utility function. The UEP method enables the model to take into account asymmetric price distribution: the skewness becomes an element of decision as well as the variation amplitude. Thus, the model maximizes the expected utility of the income as follows: 


$$
\begin{aligned}
& \text { Maximize: } E\left\{\left(U_{k}\right\}\right. \\
& U_{k}=1-\exp \left(-\left((1-\lambda) r_{\text {min }}+\lambda r_{\text {max }}\right) \times Z_{k}\right)
\end{aligned}
$$

$U_{k}$ is the utiliy of the farm income for state $k$ and $\lambda$ is a parameter reflecting variation in risk preference, and $r_{\max }$ and $r_{\min }$ are upper and lower bounds of the coefficient of absolute risk aversion. The states $k$ represent the possible level of price. In the model, we use 1000 states $k$ in order to recreate the price variation. These prices follow a normal distribution given a mean and a standard deviation (see table 1). In a simpler form, the farm income for each state $k$ is given by $Z_{k}$ in this equation:

Farm income:

$$
\begin{aligned}
& Z_{k}=\Sigma_{c}\left(\text { Area }_{c} \times\left(\text { CropYield }_{c} \times \text { CropPrice }_{c, k}-\text { CropInput }_{c}\right.\right. \\
& \left.\left.- \text { Nitrogen }_{c} \times \text { NPrice }_{k}+\text { Premium }_{c}\right)\right)+\Sigma_{a}\left(\text { Total }_{a} \times \text { MilkYield }_{a}\right) \\
& \times 305 \times \text { MilkPrice }_{k}+\Sigma_{a}\left(\text { Sale }_{a} \times \text { Weight }_{a} \times \text { MeatPrice }_{a, k}\right) \\
& +\Sigma_{a}\left(\text { Total }_{a} \times\left(\text { SlaugtherPremium }_{a}+\text { SPBM }_{a}\right)\right) \\
& -\Sigma_{a, \text { conc,p }}\left(\text { Total }_{a} \times\left(\text { ConcQuantity }_{a, \text { conc }, p} \times \text { ConcPrice }_{\text {conc }, k}\right.\right. \\
& \times 91.25+\text { Animallnput }))- \text { FixedCosts }
\end{aligned}
$$

Index $a$ indicates the type of animal (dairy cows, heifers, calves and young bulls), $c$ is used for the type of crop (wheat, corn, rapeseed, pea, maize silage, pasture, hay and grass silage), $p$ indicates the period of the year (spring, summer, autumn and winter) and conc is the type of concentrated feed for the animals (soybean meal, rapeseed meal, wheat, production concentrate and milk powder).

Regarding the endogenous variables, Total ${ }_{a}$ is the total number of animal $a$, Sale represents the number of animals sold each year, MilkYield $a_{a}$ is used for the milk yield for the dairy cow (in liters per day per cow), ConcQuantity $a$, conc, $p$ indicates the quantity of concentrated feed ingested per day (in $\mathrm{kg} /$ day/animal), $A r a_{c}$ represents the cultivated area (ha), while CropYield $c$ is the crop yield ( $\mathrm{kg} / \mathrm{ha})$ and Nitrogen is $_{\text {in }}$ ise nitrogen quantity $(\mathrm{kg} / \mathrm{ha})$ used for the fertilization.

Regarding the exogenous parameters, we consider mainly three types of parameters:

i) the parameters determining the costs such as the price of concentrated feed (ConcPrice conc in $€ / \mathrm{kg}$ ) and nitrogen fertilizer (Nprice in $€ / \mathrm{kg}$ ), the specific inputs for animals (AnimalInput $t_{a}$ which are artificial insemination, medicines, herd-book and minerals in €/animal/year) and for crops (CropInput: seed, treatments and harvesting in $€ /$ ha/year) and the fixed costs (FixedCosts: electricity, water, mechanisation, buildings, rent for land, insurance, taxes in $€$ /year) which are are specific to each type of farming;

ii) the parameters determining the outputs: the prices for milk (MilkPrice in $€ /$ liter), meat (MeatPrice in $/ \mathrm{kg}$ ) and crop (CropPrice in $€ / \mathrm{kg}$ );

iii) the parameters for the public regulation (CAP): SlaughterPremium ${ }_{a}(80$ €/head) and the special premium for bovine males $\left(\operatorname{SPBM}_{a} 210 \mathrm{€} / \mathrm{head}\right)$ and Premium which is the premium for the crop area and set-aside (370 €/ha).

There are also some technical parameters such as 305 which is the duration of the standard lactation (with the 60 days drying-up period) and 91.25 the length of a period (number of days per season); Weight $t_{a}$ is the average carcass weight $(\mathrm{kg})$. 
Table 1. Mean price and price variation for the inputs and outputs

\begin{tabular}{lcc}
\hline & 2005 price level & Standard deviation $(\%)$ \\
\hline Milk $(€ / l)$ & 0.31 & 10 \\
\hline Meat (culled cow) & 2.60 & 20 \\
Meat (young bull) & 2.90 & 20 \\
\hline Cereal crop & & \\
$\quad$ Wheat $(€ / \mathrm{kg})$ & 0.12 & 30 \\
Maize $(€ / \mathrm{kg})$ & 0.11 & 30 \\
Rape seed $(€ / \mathrm{kg})$ & 0.24 & 30 \\
Pea $(€ / \mathrm{kg})$ & 0.13 & 30 \\
\hline Concentrated feed & & 30 \\
Cereal $(€ / \mathrm{kg})$ & 0.14 & 30 \\
Soybean meal $(€ / \mathrm{kg})$ & 0.22 & 30 \\
Rapeseed meal $(€ / \mathrm{kg})$ & 0.18 & 30 \\
Chemical nitrogen $(€ / \mathrm{kg})$ & 0.15 & \\
\hline
\end{tabular}

All these exogenous parameters are fixed and do not change during the computation of the model. However, those parameters, mainly the prices and the level of CAP premiums, are modified in our scenarios in order to test the effect of the decoupling in different price contexts.

Consequently, in order to maximize the expected utility of the farm income, the model determines the optimum for the following endogenous variables: number of each type of animal (Total and Sale $_{a}$ for sale); milk yield per cow (MilkYield in $_{\text {kg }}$ per cow per day); concentrated feed and forage consumption for each type of animal and per period (in kg per animal per day per season); the crop patern ( rea $_{c}$ in ha); the level

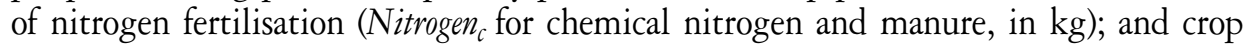
yield (CropYield in $\mathrm{kg}$ per ha).

The model tries to offer the largest choice of technical practice for crop and animal production. In order to modify the quantity of production, the farmer can use two levies: i) the number of inputs (ha of land and number of animal) and ii) the intensity of production of these inputs by modifying the crop yield (with more or less nitrogen) and the milk yield (with more or less concentrated feed). Therefore, the model has access to all possible situations, e.g.: the model can choose a full grass diet for a cow which produces 7000 litres of milk or a full maize diet for the same cow. The model will thereby calculate the optimal quantity of input and output given the relative price equilibrium for crop, meat and milk.

This is a farm level model where the modifications of input used and output produced calculated by the model do not have any retroactive effect on prices and demand on the market. This model only represents the productive behaviour of the farmers in response to price variations and policy modifications and do not integrate the possible effect on the market equilibrium of a massive and similar reaction (change in productive decision) by a large number of farmers. 


\subsection{The structural, environment and biological constraints}

\subsubsection{Structural and environmental constraints}

Regarding the farm structure, the model incorporates the agricultural area (equation 4), the milk quota (equation 5):

$$
\begin{gathered}
\Sigma_{c}\left(\text { Area }_{c}\right) \leq \text { Available land } \\
\Sigma_{a}\left(\text { Total }_{a} \times \text { Milk Yield }\right) \times 305 \leq \text { Milk quota }
\end{gathered}
$$

As regards building constraints, we assume that the number of cows can increase by $10 \%$ in comparison to the base year: the implementation of the programme to control pollution of agricultural origin has motivated many dairy farmers to construct new buildings with more places than required (equation 6).

$$
\Sigma_{a} \text { Total }_{a} \leq \text { Building capacity } \times 1.1
$$

Regarding crops, the model meets the requirements for rotation frequency and cropping pattern (Mosnier et al., 2009): the spring crops succeed the winter crops.

$$
\text { Area Wheat }+ \text { Area }_{\text {RapeSeed }}=\text { Area }_{\text {MaizeSilage }}+\text { AreaCorn }_{\text {Areapea }}
$$

We also include three environmental measures as constraints in the model: i) the Nitrate Directive 91/676/EEC requires that farmers cannot exceed organic nitrogen application rates of $170 \mathrm{~kg}$ per hectare (slurry and manure); ii) farmers have to keep grasslands aged over 5 years; iii) in addition to the CAP premiums, a premium for the maintenance of extensive livestock systems or "premium for grassland" is attributed $(75 \mathrm{E} / \mathrm{ha}$ ), if there is at least $75 \%$ of grass in the total farm area and if the stocking rate is below 1.4 "livestock units" per hectare of grass.

\subsubsection{Technical and biological constraints}

Thornton and Herrero (2001) show a wide variety of separate crop and livestock models, but the nature of crop-livestock interactions, and their importance in farming systems, makes their integration difficult. That is why, in order to precisely describe the operation of a dairy farm, this model considers four important characteristics: i) the seasonality of labour and grass production, ii) the response of crop yield to nitrogen use, iii) the non-linearity of milk yield per cow, and iv) the interaction between crop and animal production.

i) Four periods $\mathrm{p}$ (spring, summer, autumn and winter) are distinguished in the model. It allows for seasonal specification of grass production and grassland use (Berentsen et al, 2000). Seasonal variations enable us to integrate differences in the growth potential of grass during the growing season as well as the evolution of the nutrient content of grass. Moreover, we introduce seasonal labour constraints by allocating labour needs to each activity according to the work peaks (harvesting and calving). It is assumed that the farmers and their family/associates execute all the work, and thus there is no option to hire temporary labour. The model is more able to reflect temporal conditions thanks to the addition of these parameters. 
For each period $p$ :

$$
\begin{aligned}
& \Sigma_{a}\left(\text { WorkingTime }_{a, p} \times \text { Total }_{a}\right)+\Sigma_{c}\left(\text { WorkingTime }_{a, p}\right. \\
& \left.\times \text { Area }_{c}\right)+ \text { FixedLabour } \leq \text { AvailableLabour } p \times A W U
\end{aligned}
$$

The global working time per period (sum of the working time per animal; the working time per ha of crop and the fixed labour) has to be lower than the labour availability per period times the number of annual work unit $(A W U)$. It is important to note that, even if we consider four periods, the optimization of the production plan is made for the year to come; there is no adaptation of the productive strategy through time (annual static model).

ii) Crop yield depends on the quantities of nitrogen used. Godard et al. (2008) formulated an exponential function, which satisfies economic requirements for attaining a mathematical optimum (the yield curve has to be concave and strictly increasing) and is consistent with its expected agronomic shape and with parameters with an agronomic interpretation.

$$
\text { CropYield } c=\text { MaxYield } c-(\text { MaxYield } c \text { MinYield }) \times e^{-\sum_{i} t_{i} \times \text { Nitrogen }_{i}}
$$

where MinYield $d_{c}$ and MaxYield are respectively the minimal and maximal yield (different according to the type of farming and its level of intensification); $t_{i}$ represents the rate of increase in the yield response function to a nitrogen source $i$ (e.g. manure, slurry, chemical nitrogen) the quantity of which is $N_{i}$. This enables us to take the increasing price of nitrogen into account and also the flow of organic nitrogen (such as manure) on the farm (Manos et al., 2007).

iii) In order to give more flexibility to the model, milk production per cow is not fixed. Farmers have the possibility to choose the milk yield per animal in a range of 1000 litres below the dairy cow's genetic potential. It is also possible for farmers to produce beyond the genetic potential (Brun-Lafleur et al., 2009); in this case, nutritional requirements needed to produce one litre of milk are increased (from 0.44 to 1.2 energy units per litre of milk, and from 48 to 140 units of protein per litre of milk) (Faverdin et al., 2007).

$$
\begin{aligned}
& \text { NormalMilkYield }_{a}+\text { MarginalMilkYield } \\
& \text { GeneticPotential }-3.28 \leq \text { NormalMilkYield }_{a} \\
& \text { Geld } \\
& \leq \text { GeneticPotential }
\end{aligned}
$$

With: NormalMilkYield: the milk yield beyond the genetic potential and Marginal MilkYield ${ }_{a}$ the milk yield above the genetic potential;

iv) We also very accurately represent the feeding system. The quantity ingested per cow per day is determined by using i) nutritional requirements in biological unit $b$ (energy and protein), and ii) the composition of forages and concentrated feed in equation 12 (INRA, 2007).

For each nutrient unit $b$ and period $p$ :

$$
\begin{aligned}
& \Sigma_{a}\left(\text { Total }_{a} \times\left(M_{a, b} \times 365+\left(\text { NormalMilkYield }_{a} \times N R_{a, b}\right.\right.\right. \\
& \left.\left.\left.+ \text { MarginalMilkYield } \times \text { MarginalLR } R_{a, b}\right) \times 305\right)\right) \leq \Sigma_{a, c}\left(\text { Total }_{a}\right. \\
& \left.\times\left(\text { ForageQuant }_{c, p, a} \times \text { ForageNutrient }_{c, p, b} \times 91.25\right)\right) \\
& +\Sigma_{a, \text { conc }}\left(\text { Total }_{a} \times\left(\text { Conc Quantity }_{\text {conc }, p, a} \times \text { ConcNutrient }_{\text {conc }, p, b} \times 91.25\right)\right)
\end{aligned}
$$


With: $M R_{a, b}$ the maintenance requirement (in energy and protein);

NormalLR $R_{a, b}$ the lactation requirement (in energy and protein for one liter of milk) for the milk yield beyond the genetic potential and MarginalLR $R_{a, b}$ the lactation requirement (for the milk yield above the genetic potential;

ForageNutrient $t_{c, p, b}$ the forage nutrient content (in energy and protein per $\mathrm{kg}$ of forage) and ConcNutrient conc,p,b the concentrated feed nutrient content;

ForageQuant $c_{c, p, a}$ the forage consumption $(\mathrm{kg})$ for each $\operatorname{crop} c$, each period $p$ and each type of animal $a$ and ConcQuantity $y_{c, p, a}$ the concentrated feed consumption (in kg per day per concentrate per period per animal);

The global nutritional needs for the herd must not exceed the availability in forage and concentrate feed. Moreover, the forage consumption (for each type of forage $c$ ) has to be lower than the forage production:

For each type of crop $c$ :

$$
\Sigma_{a, p}\left(\text { Total }_{a}\left(\text { ForageQuant }_{c, p, a} \times 91.25\right)\right) \leq \text { Area }_{c} \times \text { CropYield }_{c}
$$

Figure 1 shows how the model deals with the dynamic of the animal population. The central element of the model is the dairy cow. Given the price equilibrium between the different productions, the model calculates the optimal milk yield and then the number of cows to produce the milk quota. The restocking rate is different for the four farms studied (see table 2). Because it is a static annual model, there is no feedback between heifers and dairy cows. The young bull production is only possible

Figure 1. Dynamic of the herd structure

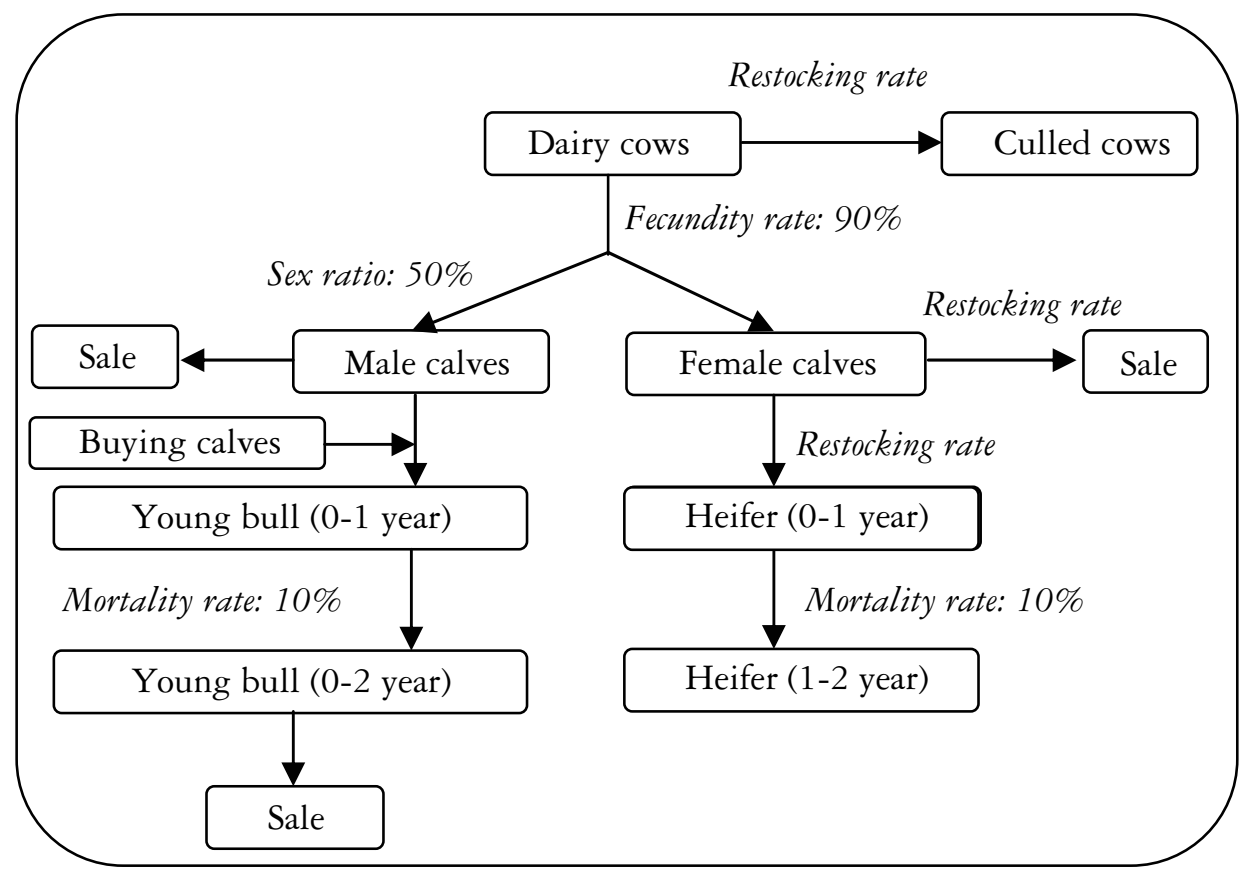


Table 2. Specific farm data for the base year

\begin{tabular}{lcccc}
\hline & Grass based & Semi-intensive & Milk + cereals & Milk+ young \\
& Farm & Farm & Farm & bulls Farm \\
\hline Share of the system in France $(\%)$ & $8 \%$ & $22 \%$ & $30 \%$ & $18 \%$ \\
Total area (ha) & 78 & 50 & 137 & 100 \\
Milk quota (liters) & 285000 & 290000 & 460000 & 400000 \\
Annual Work Unit $(\mathrm{nb})$ & 1.7 & 1.5 & 2.0 & 2.7 \\
Building capacity $(\mathrm{nb})$ & 62 & 37 & 59 & 122 \\
Restocking rate $(\%)$ & 0.25 & 0.35 & 0.37 & 0.4 \\
Dairy genetic potential $(\mathrm{l} / \mathrm{year})$ & 6000 & 8500 & 8500 & 9000 \\
Max crop yield $(\mathrm{kg} / \mathrm{ha} /$ year $)$ & & & & \\
Wheat & 6100 & 8100 & 8100 & 8100 \\
Corn & n.a. ${ }^{1}$ & n.a. & 10000 & n.a. \\
Rapeseed & n.a. & n.a. & 3800 & n.a. \\
Pea & n.a. & n.a. & 5000 & n.a. \\
Maize silage & 10200 & 12200 & 15200 & 14200 \\
Grass Silage & 8500 & 8500 & 8500 & 8500 \\
Grass & 8500 & 7000 & 6000 & 6000 \\
Hay & 8500 & 7500 & 7500 & 7500 \\
Milk price $(€ / \mathrm{l})$ & 330 & 310 & 310 & 310 \\
Meat price $(€ / \mathrm{kg})$ & 3.0 & 2.6 & 2.6 & 2.6 \\
\hline
\end{tabular}

1 n.a.: not available

for the Milk+Young bull farm. For the other, all the male calves are sold. The number of young bulls (and bought male calves) is determined by the profitability of the fattening activity in comparison with cereal and milk production.

\subsection{Calibration: one model for four types of farming}

In France, there is a high diversity of dairy farms in terms of location (mountains/ plains), intensification (intensive/extensive), feeding system (pasture, maize silage) and specialization of production (specialized/diversified). In this context, our choice focused on the four main types in the plains regions of France: these regions are not located in the less favourable areas and do not benefit from these specific supports. We exclude the mountain areas which have a different productive system for producing milk. The data come from the annual survey of the Institut de l'Elevage (2008) with more than 600 dairy producers in the plains regions. Each type of farming is the result of the aggregation of several farms (from 20 to 45) representing similar structures and production methods (see table 2).

1. The "Grass-based farm" represents farms that have opted for an extensive production system where almost all of the UAA is cultivated in grassland and the ration of dairy cows consists mainly in grass (pasture, hay or silage). The milk yield per cow is low (6 000 liters per year) but the prices of milk and meat are higher thanks to a better milk composition and heavier carcasses (Normand or Montbeliarde cow). 
2. The "Semi-intensive farm" applies a more productive system, especially since it has only a 50 ha of UAA, (28 ha less than the Grass-based Farm for an equivalent quota). The producer uses a more intensive technique based on corn silage and higher milk yields per cow. This helps to reduce the number of cows required for the production of milk quota and thus free up land for grain production.

3. The "Milk + cereals farm" has a larger structure: 137 hectares and a quota of 460,000 liters of milk. Dairy production is the main activity on the farm, but it pursues a strategy of intensive production. The aim is to minimize the number of dairy cows in order to develop cereal production (wheat, rapeseed, maize and pea).

4. The "Milk + Young bulls farm" is the most representative system of the area: $30 \%$ of dairy farms. It has the same characteristics as the previous type, but young bull fattening activity replaces the cereal activity. The model can choose to fatten (or not) the males and buy (or not) other male calves to reach 80 young bulls. These animals are slaughtered when they are 20 months old. The young bulls benefit from the male slaughter premium ( $80 € /$ animal) and the special premium for male bovines ( $210 € /$ animal).

The farms of this study are located in plains areas and do not benefit from a protected designation of origin. There are no specific requirements to produce milk in order to receive some special promotion (better milk price for giving the cows a specific feed...).

A calibration step is necessary: the model's results and the empirical observations have to be close. We choose the year 2005 as a baseline (i.e. before the implementation of the Luxembourg agreement). The calibration of the model is correct when four main criteria are close to those actually observed: income, milk yield per cow, the share of cereals in total area and the proportion of maize silage in the forage area. To succeed in obtaining acceptable values for these criteria, we modified several technical coefficients in the model, such as the cow's genetic potential and mainly the maximum yield for crops $($ Max Yield $)$. Indeed, an overhigh forage yield results in a reduction in costs related to animal nutrition and an increase in income due to greater sales of cereal crops (because of less forage area). Therefore we adjusted the crop yields by successive tests until obtaining a correct share of cereals in the usable agricultural area and a portion of corn silage in the forage area (see table 3).

Table 3. Calibration results

\begin{tabular}{lcccccccc}
\hline & \multicolumn{2}{c}{ Grazier Farm } & \multicolumn{2}{c}{$\begin{array}{c}\text { Semi-intensive } \\
\text { Farm }\end{array}$} & \multicolumn{2}{c}{$\begin{array}{c}\text { Milk +cereals } \\
\text { Farm }\end{array}$} & \multicolumn{2}{c}{$\begin{array}{c}\text { Milk + Young } \\
\text { bull Farm }\end{array}$} \\
\hline & Real & Model & Real & Model & Real & Model & Real & Model \\
\hline Income $(\mathrm{k \epsilon})$ & 49,9 & 54,1 & 53,4 & 55,7 & 114,8 & 120,6 & 120,0 & 120,4 \\
Milk yield (l/VL) & 5400 & 5290 & 8500 & 8500 & 8500 & 8500 & 9000 & 8920 \\
Cereals/UAA (\%) & $12 \%$ & $14 \%$ & $30 \%$ & $33 \%$ & $60 \%$ & $66 \%$ & $22 \%$ & $18 \%$ \\
Silage Maize/forage (\%) & $6 \%$ & $8 \%$ & $44 \%$ & $49 \%$ & $55 \%$ & $59 \%$ & $65 \%$ & $64 \%$ \\
\hline
\end{tabular}


The income calculated by the model is then close to the observed one. The coefficient of risk aversion was differently calibrated since there is no reference for this value. The use of the UEP method allows us to calculate the risk premium for each type of farm. Bontems and Thomas (2000) show that the ratio risk premium/income should be around $5 \%$. Thus, the value of the coefficient of risk aversion is about 0.5 for the four types of farming.

\section{Scenario analysis}

The model gives the opportunity to study the impact of the decoupling on the economic performance of farmers and their productive choices: allocation between animal and vegetable production, intensification or extensification strategy. We compare the baseline situation to two different scenarios:

i) The baseline is the year 2005, before the implementation of the CAP reform. Therefore, dairy farmers receive fully coupled payment based on the number of ha of crops and number of head cattle. The price for milk, cereals, meat and inputs is the one observed for this period (table 4).

Table 4. Share of decoupling and price variation according the scenarios

\begin{tabular}{lccc}
\hline & $\begin{array}{c}\text { Baseline } \\
\text { (fully coupled) }\end{array}$ & $\begin{array}{c}\text { S1 Partial } \\
\text { decoupling }\end{array}$ & $\begin{array}{c}\text { S2 Partial } \\
\text { decoupling and } \\
\text { price variation }\end{array}$ \\
\hline Premium & (Value) & (share of decoupling) \\
\hline Crop premium & $380 € /$ ha & $75 \%$ & $75 \%$ \\
Set-aside premium & $380 € /$ ha & $100 \%$ & $100 \%$ \\
Slaughter premium & $80 € /$ head & $60 \%$ & $60 \%$ \\
SPBM & $210 € /$ head & $100 \%$ & $100 \%$ \\
Direct milk aid & $35.5 € /$ liter & $100 \%$ & $100 \%$ \\
\hline Price & & & 0.29 \\
Milk (€/liter) & 0.31 & 0.275 & 0.18 \\
Cereal (wheat) in $€ / \mathrm{kg}$ & 0.12 & 0.12 & 2.9 \\
Meat (culled cow) in $€ / \mathrm{kg}$ & 2.6 & 2.6 & 0.32 \\
Soybean meal in $€ / \mathrm{kg}$ & 0.22 & 0.22 & 0.25 \\
Fertilizer (nitrogen) in $€ / \mathrm{kg}$ & 0.15 & 0.15 &
\end{tabular}

ii) S1 is the implementation of the CAP reform (decoupling, modulation, and the obligation to maintain the surfaces in permanent pasture). France chose to not fully decouple some subsidies (the decoupling is partial): the crop premium is partially decoupled $(75 \%)$ as well as the slaughter premium (60\%) and other animal premiums (suckler cow, ewe); but direct subsidies based on the milk quota, special premiums for bovine males (SPBM) and setaside premiums are fully decoupled (table 4). Moreover, in France, the single payment is granted on the basis of the amount of subsidies allocated during 
the reference period 2000-02 (historical model). Therefore, it remains closely correlated to the farm's size, i.e. the production factors: land, animals and milk quota. In order to take into account these elements, the objective function of the model is slightly modified between the baseline and scenario S1. The value of parameters Premium, SlaughterPremium ${ }_{a}$ and $S P B M_{a}$ are respectively reduced by $75 \%, 60 \%$ and $100 \%$. A new term is then included in the objective function: the Single Farm Payment. It is the sum of the decoupled amount base on the reference situation and reduced by $5 \%$ (for the modulation). Regarding the prices for inputs and outputs, all things are equal between the baseline and S1 except for the milk price which is reduced. Indeed, in order to decrease distortion effects on the market, the intervention price for milk is reduced and compensated for farmer by the direct milk aid included in the single farm payment $(35.5 € / t$ of milk).

iii) The S2 scenario proposes, in addition to the implementation of the decoupling, to analyse the impact of rising prices on the productive strategy. Therefore, the structure of the model is the same as in S1 but the average prices considered are the average prices for 2010 (table 4). This period reflects a much more profitable situation for farmers with higher prices for output ( $290 € / t$ of milk and $180 € / t$ of wheat). This could lead farmers to modify their productive plan in order to increase their income. The S2 scenario investigates how far they can intensify the production and if the equilibrium between milk and crop is modified.

In these simulations, the farm structure (land, workforce, milk quota) is constant, and the model does not take into account investments (land acquisition or building enlargement...). This analysis is focused on the short-term impacts of the implementation of decoupling: changes in production, and income evolution.

\subsection{The decoupling: a stable income}

The first item discussed concerns the impact of the decoupling on the economic performance of the farms studied (S1). In the S1 scenario, the implementation of the decoupling has little influence on economic performance (see table 5). The income is stable for two reasons. The $5 \%$ modulation (budgetary transfer of support from the first to the second pillar for rural development) of direct payments decreases the total output. But this is partly offset by a decrease of variable costs due to the substitution of maize silage by grassland (grass-based production is cheaper than silage-based production). Even if income is stable, the weight of the payment in income rises strongly with the allocation of the direct milk aid as compensation for the decrease of institutional prices. The decoupling increases the dependence of farmers on direct public support as showed by Chatellier (2006). There is also a great disparity between intensive and extensive systems: farms with cereal or fattening activities receive the largest amount of subsidies.

The decoupling causes a significant decline in the shadow price of an additional litre of milk quota (equation 5) (from - $8 \%$ to - 20\% depending on the type of farming) and an additional hectare of land available (equation 4) (from $-20 \%$ to $-50 \%$ ). 


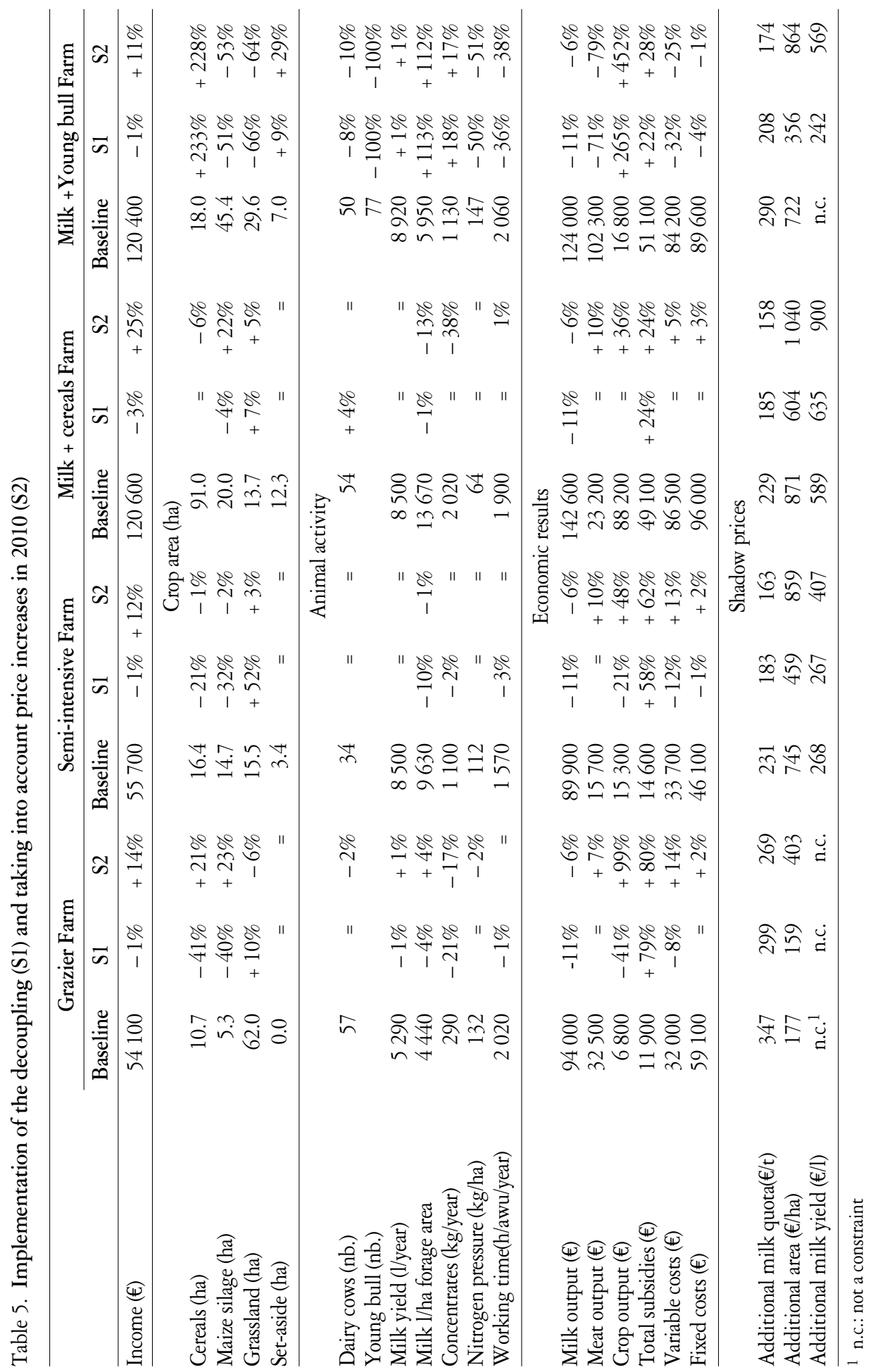


Regarding milk shadow price, the work of Bouamra-Mechemache et al. (2008) and Moro et al. (2005) within the framework of the European Dairy Industry Model project confirms these results. The shadow price estimated by their computable general equilibrium model ranges between $141 € / t$ to $163 € / t$ (50\% of the price of milk) for the French dairy farm after the CAP reform. Nevertheless, these shadow prices remain positive and, consequently, expanding the farm is economically beneficial. It is reassuring that the results of the farm-level model are close to those of the general equilibrium model, and suggest that the calibration of the model is precise.

In the S2 scenario, we simulate the reform with the rise of prices which occurred in 2010 (see table 4). This increase in agricultural prices improves the income for all the types of farming studied, from $11 \%$ to $25 \%$ (table 5 ). This situation, very economically beneficial for the farms, helps to reduce the share of direct payments in income. In these more favourable price conditions, farmers seek to increase their cereal production. Thus, farmers convert into cereals those areas which they had previously held under grass. The decline in gross margin for crop production caused by the decoupling is more than offset by the rise in prices: the shadow price of an additional hectare of land increases by $20 \%$ between the baseline and S2 (and more than double for the grass-based farm). The increasing for cereal price is higher than the increasing for milk price, which causes a reduction in shadow price of milk. However, the rising price for cereal is not sufficient to cause a decrease in milk production. The model therefore proposes a production system close to the 2005 situation in its pattern crops and livestock composition. The milk + cereals farm, on the contrary, reduces a little its share of cereals in favour of its maize silage area. Indeed, with the rise of cereal prices, concentrated feed prices also increases. Therefore, farmers reduce the quantity of concentrated feed for the cows (from 2,020 kg to $1,250 \mathrm{~kg}$ ) and increase the share of forage in the diet.

\subsection{The decoupling: an incentive to produce with more grassland?}

This section pays special attention to the distribution between silage maize and grassland in the forage area (intensification strategy versus extensification strategy) with the partial decoupling of the crop premium in France.

In S1, the implementation of the reform leads to the extensification of dairy production with a decrease in cereal and silage maize cropping and an increase in grassland (for the grass-based, semi-intensive and milk + cereals farms: see table 5). The decoupling of $75 \%$ of crop premium (maize silage included) rebalances the choice between grass and maize but is not enough to encourage farmers to comply with the criteria for the premium for grassland (the grass-based farm is the only one to benefit from this premium). These results confirm those highlighted by Ridier and Jacquet (2002). Regarding environmental criteria (nitrogen application, livestock unit per ha of forage, and milk produced per hectare of forage), the decoupling has a positive impact and encourages farmers to extensify their production. With the increase of grassland, the measure of maintaining surfaces in permanent pasture is never a constraint. Moreover, none of the farms studied see their production limited through the application of the Nitrate Directive. 
Nevertheless, the model does not take into account some other elements, which affect farmers' behaviour. Many farmers will continue to focus on maize, since feeding management of dairy cows based on grass is more complex (nutritional values constantly change). Moreover, the labour constraint may curb the use of pasture, since it requires driving the animals to the plots and bringing them back for milking. Similarly, the greater use of milking robots requires grassland around the robot, which must be accessible at all times. Moreover, in France, the price for milk produced during autumn and winter is higher than the one produced in spring and summer. Therefore, this price seasonality encourages farmers to produce milk for this period and also lead to a greater use of maize silage than grassland.

With the increasing price that occurred in 2010 (S2), farmers developed the crop production at the expense of grasslands. Figure 2 shows the evolution of the share of cereals in the total area according to the cereal price in this decoupled situation: the more intensive farms, which have the highest yields and the best techniques, take advantage more rapidly of a lower price and thus reach their rotation limits faster. At the same time, all types of farming reduce the share of grass in the diet of dairy cows and replace it by maize silage to intensify milk production. The intensity of this decline depends primarily on the yield and on the production costs of cereal crops and maize silage. We can also see that the "grass-based" farm chooses to no longer meet the criteria for the "premium for grassland" when cereal prices exceed $220 € /$ ton.

As we can see, the increase of cereal price encourages farmers to free up land for crop production. However, it appears that maintaining milk production is always a priority for farmers, regardless of the price considered (milk and cereals). Indeed, the

Figure 2. Proportion of cereals in the total area according to the cereal prices

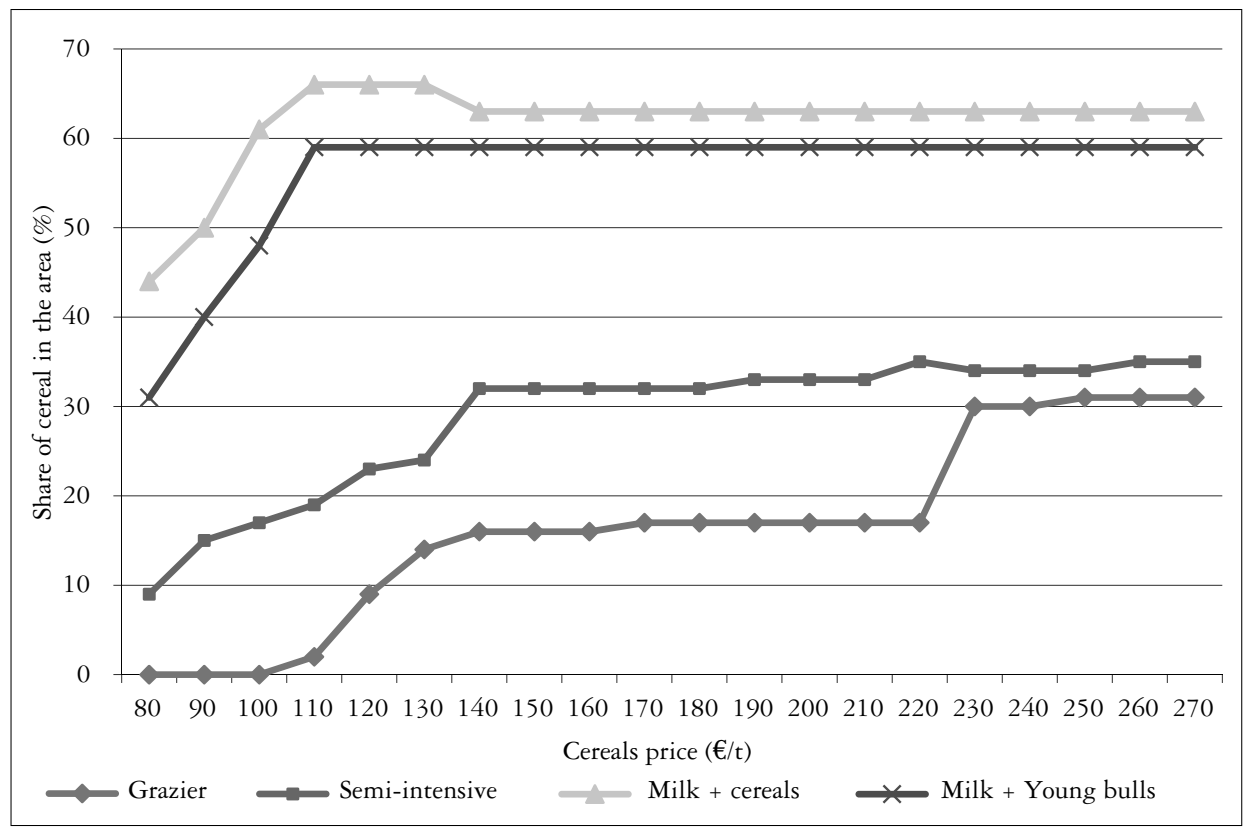


costs incurred to establish a dairy operation are often too high for farmers to consider abandoning milk for cereal production. This is especially true because the agricultural area of dairy farms is often far below the threshold of profitability traditionally met with amongst specialized crop farms.

\subsection{The decoupling: cessation of the fattening activity?}

In this section, we are especially interested in the young bull fattening activity. The premium for these animals (SPBM) is totally decoupled (table 4), leading to a decrease in gross margin per animal of $210 €$ (plus $48 €$ for the slaughter premium). Our question focuses on maintaining this production, which benefited from large amounts of aid.

The decoupling encourages farmers to stop the fattening activity in both scenarios. The "Milk + Young bull" farm completely ceases this production and uses the freed area to produce cereals (table 5). Milk yield per cow is increased to the maximum (9000 litres/year) in order to reduce the number of cows and thus the requirement in maize silage. Therefore, the farmer can produce more cereals: the model offsets the profitability of the feedlot with cereal crops. This change of production allows a decrease in working time $(-40 \%)$, thus freeing permanently $1.2 \mathrm{AWU}$. Stopping the production of young bulls also decreases nitrogen emission (-50\%).

Figure 3 shows that the fattening activity is conditioned both by meat and cereal prices because these are in competition for the land. When cereal price increases from $100 € / t$ to $180 € / t$ in a non-decoupled situation (top of figure 3), the meat price has to increase to more than $3 € / \mathrm{kg}$ to make the fattening activity more profitable than cereals. However, with the full decoupling of the SPBM, the increase in the price of meat in S2 is not sufficient to encourage farmers to maintain the fattening activity. In this situation (with cereal price at $180 € / \mathrm{t}$ ), the price of meat needs to increase by $30 \%$ $(3.9 € / \mathrm{kg}$ ) to encourage farmers to start fattening bulls. Moreover, the cereal price rise also affects the concentrated feed of which bulls are large consumers. The full decoupling of the SPBM is highly disadvantageous to this production: the price of meat has to increase by almost $1 € / \mathrm{kg}$ to offset this effect. In other words, farmers do not lose money by continuing to fatten bulls, but they could earn more by replacing this production by cereals.

\section{Discussion}

Theoretically, the decoupling of aid has no effect on income because it does not affect the amount of payment; only the method of payment differs. However, decoupling can change production activities by making some products less attractive than before. The effect of direct payments on agricultural markets is one of the controversial issues in the WTO Doha Round agenda, and is generating considerable discussion both in these negotiations and in the economics literature. Dewbre et al. (2001) show that market price support is a relatively inefficient means of transferring income to farmers, and, furthermore, that it does so at the expense of relatively large distortions in world markets. They show that, in contrast, land-based payments are highly effective at 
Figure 3. Fattening of young bulls according to the meat price and cereal price

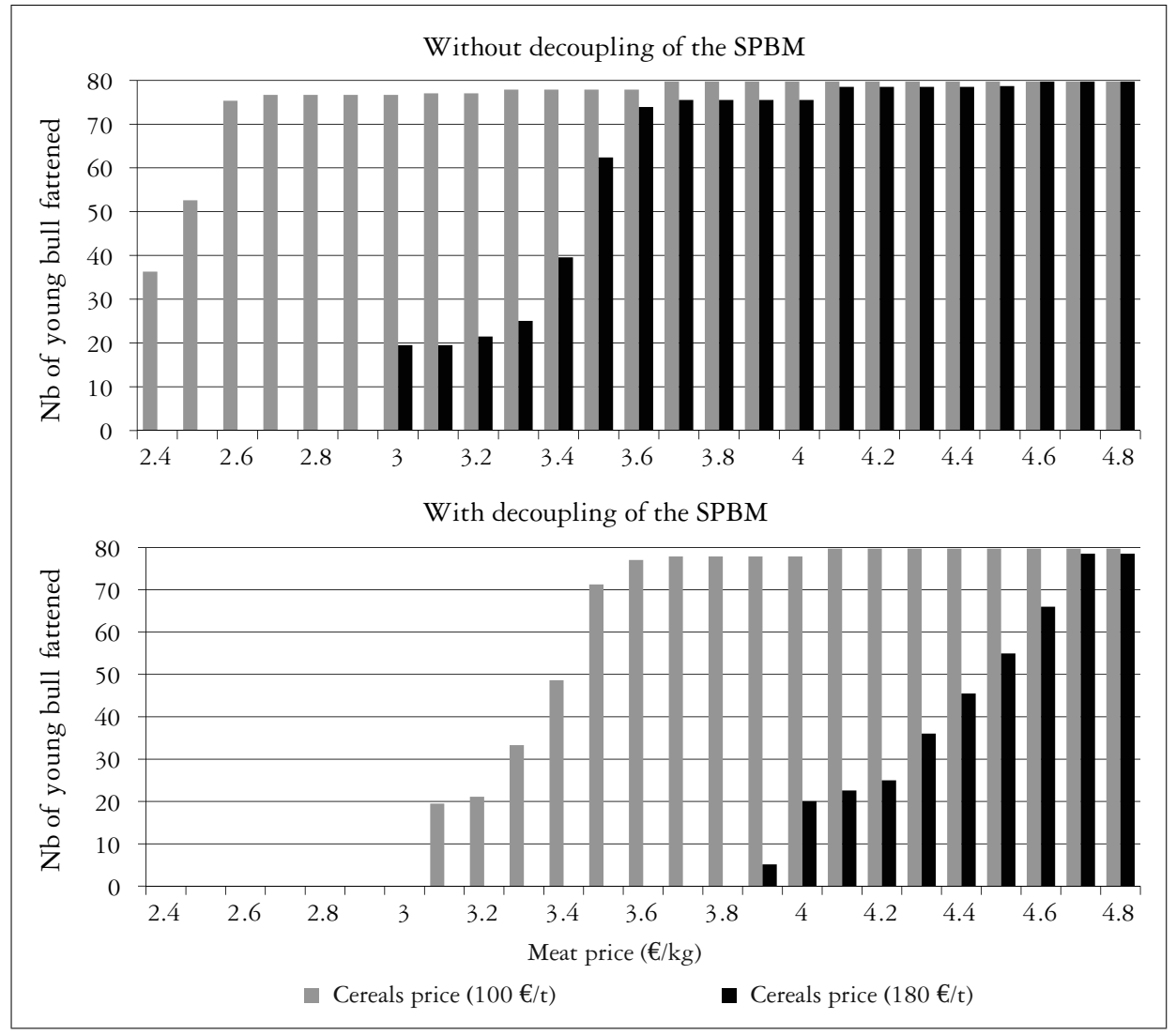

transferring income to farmers, while reducing world market price impacts. However, according to Chau and De Gorter (2005) direct land-based payments may induce inefficient farmers, who are not able to cover their fixed costs and who, without the payment, would exit the market in the long-run, to keep on producing. Moreover, Guyomard et al. (2004) show that land-based payments also influence farmers' productive behaviour: farmers choose to produce the most profitable activities and the landbased and headage-based payments increase the profitability of such activities. Therefore, coupled payments also have distortionary effects on price, and encourage inefficient farmers to keep on producing.

The European Union decided to implement an income support program by fully decoupling the previous input-based payments. Cahill (1997) defines a policy as fully decoupled if it does not influence the production decisions of farmers receiving payments, and if it permits free market determination of prices. It is a concept centered on the adjustment process and not only on equilibrium values. He also defines effective full decoupling as that which results in a level of production and trade equal to what would have occurred if the policy were not in place. The OECD (2001) shows that decoupled policy always have effects on production, and describes several effects 
leading to this result: i) risk-related effects referring to policy measures that, usually, increase the wealth of the farmers and thus the incentive to produce for risk-averse farmers; ii) dynamic effects which relate to the policy measures that change current and future incomes and may affect current decisions. In the long-term perspective, farmers make intertemporal choices involving current and future income. Dynamic effects commonly affect investment decisions. As a short term model (annual), this tool cannot study the dynamic effects.

The results from the model confirm what has been shown by these previous studies: farm income does not change, but the price is now the main factor in the production decision, thereby changing the balance of production. In addition, these results correctly reflect what occurred in French cereal production after the implementation of the reform. The French Agriculture Ministry database (Agreste) shows that the cultivated areas in soft wheat increased from 4.78 million hectares in 2007 to 5.07 million hectares in 2008, following the rise in price, and then decreased to 4.75 million hectares in 2009 with the drop in price. The evolution was similar for maize and rapeseed. In this case, the decoupling of subsidies modifies farmers' behaviour: it restores to prices their role as indicators of the market situation, and farmers take their decisions based on those prices. The model also gives a good simulation of the evolution of dairy production in France. Despite the decoupling, the dairy activity remains the most profitable enterprise for farmers who have a limited agricultural area.

However, after four years of direct payments, we observe a difference between the model results and real farmers' choices, especially for beef production. The Institut de l'Elevage (2010) shows that the number of young bulls did not decrease in France in 2008 and 2009, despite implementation of full decoupling.

Theoretically, if the direct payments are supposed to have minimum effects on production, we identify several links between direct payments and farm production, which can explain the observed difference.

i) Long-term production requirements. Agricultural production is a long-term activity, and farmers cannot change their system in a short time. Farmers develop their production enterprises (livestock fattening and cereals for instance) within the framework of their labour organization, their use of equipment, and also the financial position of their farm, and these elements cannot be easily challenged.

ii) Eligibility criteria for the payment. Farmers have to meet the crosscompliance conditions (environmental and animal welfare measures) to secure the payment. They also have to maintain the land in a good agronomic condition. These eligibility criteria may also create a link between payments and production.

iii) Sociology/psychology of the farmer. Some of these elements can also influence farmers' decisions. For example, cessation of fattening means not using an important set of buildings. Most farmers do not consider not using their buildings to their full capacity even if it is more advantageous from a business point of view. 
iv) Anticipation of a new reform. Farmers are all aware that the CAP will be subject to further reform in 2013. Direct payments are now based on historical references, but farmers do not yet know the modalities of the future CAP reform. Some of them, anticipating the next reform, may want to maintain production in order to justify future payments (re-coupled or not).

v) Trade organization. Farmers are price takers, and have no influence on prices, which are exogenous to the model. For the fattening activity, many farmers produce under a contract with a slaughterhouse. It is reasonable to assume that these companies will maintain this contractual policy to ensure sufficient production volumes and avoid significant price variations. Farmers who work with a company under a contract (with a known price for a period) are less likely to alter their production.

vi) Value of property assets. Hennessy (1998) shows that direct payments modify the wealth of farmers and thus the incentive to produce for risk-averse farmers. Usually, policy measures increase expected farm income and reduce farm income variability. For a risk-averse farmer, this may lead to two distinct effects. The first is an insurance effect that results from the reduced income variability. The second is a wealth effect arising from the increased expected income, leading the farmer to adopt riskier behaviour. Both the insurance and the wealth effects may contribute to increased production.

The theoretical effect of decoupling, shown by the model, is not observed for beef production. We suggest that when farmers own the factors (land, buildings, machines and animals in particular), they try to use these inputs, even though they could increase their income with another productive combination. Femenia et al. (2010) show that the effect of the direct payments on wealth is underestimated for farmers who own the factor (land) on which payments are based. The capitalization of agricultural income support programs in farmland prices generates large wealth effects. These effects are a consequence of the importance of income support in farming profits, and generate modest changes in production levels.

\section{Conclusion}

The farm-level mathematical programming method is suitable for analysing the impact of public policy on dairy farmers' behaviour. This method allows placing the technical, biological, structural, environmental and regulatory realities at the heart of the producer's choice. Because we consider the interactions between types of production (both plant and animal), the main laws of biological response and the seasonality of agricultural production, the model represents, as realistically as possible, farmers' behaviour, and supplies economic, technical and environmental responses to the implementation of the decoupling. Moreover, by applying this model to four types of dairy farm, we can identify if the CAP reform causes different impacts according to the technical system. However, the limitations of the method based on instantaneous adjustment of production factors and perfect information should be kept in mind, along with the idea that the actors are primarily guided by the desire to maximize their income (while other considerations may play a more important role). Moreover, 
model prices are not endogenous variables, i.e. producers do not make their decisions in light of the evolution of global supply. Based on the current construction, some improvements are possible, such as to integrate other goals (such as minimization of labour and minimization of environmental impacts) into the objective function. In a context of increased variation in prices, the UEP method could be modified to better integrate farmers' expectations facing the direction (positive or negative) of price changes. Moreover, if this type of model is suitable to study the short-term impact of an evolution in public policy, it cannot predict a long-term evolution without taking into account changes in the farm structure.

In terms of public policy, this study has confirmed that the decoupling of supports to agriculture theoretically encourages dairy farmers to adopt a more extensive production system. The full decoupling of crop premium encourages farmers to use a larger share of grass in the cow's diet instead of maize. All things being equal, and given the considered prices, the decoupling also encourages farmers to stop fattening bulls. This enterprise has to face a great loss of profitability with the full decoupling of the SPBM (210€/head). The increase in the price of agricultural commodities has a positive impact on the economic results, but it does not change the situation for young bulls, and contributes to an increase in cereal areas. However, the CAP reform partially reaches its goal of restoring to prices their role as indicators of the market situation. Indeed, after three years of decoupling, we observe that farmers react to price changes for cereals, but not for beef. We highlight the fact that, when farmers own their assets, decoupling has little effects on production.

This model can be used to discuss the recent proposals for CAP reforms from the European Commission in November 2010 (European Union \& European Commission 2010). These include a "greening" of the CAP, the setting-up of instruments to better manage price variation and confirm the abolition of milk quotas by 2015. This last point leads to important questions for dairy producers and will certainly change the productive equilibrium on French dairy farms. It will be important to study the impact of this decision on the balance of price and quantity, but also an individual perspective to identify the productive levers available to farmers to adapt their production. The model developed in this paper may help provide some answers to this question.

\section{References}

Berentsen P.B., Giesen G.J. and Renkema J.A. (2000) Introduction of seasonal and spatial specification to grass production and grassland use in a dairy farm model, Grass and Forage Science 55, 125-137.

Bontems P., Thomas A. (2000) Information value and risk premium in agricultural production: the case of split nitrogen application for corn, American Journal of Agricultural Economics 82, 59-70.

Bouamra-Mechemache Z., Jongeneel R. and Requillart V. (2008) Impact of a gradual increase in milk quotas on the EU dairy sector, European Review of Agricultural Economics 35, 461-491. 
Brun-Lafleur L., Delaby L., Lassalas J., Fargeton M., Husson F. and Faverdin P. (2009) Predicting the energy $\times$ protein interaction on milk production and composition in dairy cows, Rencontres Recherches Ruminants.

Cahill S.A. (1997) Calculating the rate of decoupling for crops under CAP/oilseeds reform, Journal of Agricultural Economics 48, 349-378.

Chatellier V. (2006) Le découplage et les droits à paiement unique dans les exploitations laitières et bovins-viande en France, Cabiers d'Economie et Sociologie Rurales 78, $2-28$.

Chau N., De Gorter H. (2005) Disentangling the Consequences of Direct Payment Schemes in Agriculture on Fixed Costs, Exit Decisions, and Output, American Journal of Agricultural Economics 87, 1174-1181.

Dewbre J., Anton J. and Thompson W. (2001) The transfer Efficiency and trade effects of direct payments, American Journal of Agricultural Economics 83, 1204-1214.

European Commission (2010) The CAP towards 2020 - Meeting the food, natural resource and territorial challenges of the future, Brussels, European Union.

Faverdin P., Delaby L. and Delagarde R. (2007) L'ingestion d'aliments par les vaches laitières et sa prévision au cours de la lactation, Productions Animales 20, 151-162.

Femenia F., Gohin A. and Carpentier A. (2010) The decoupling of farm programs Revisiting the wealth effect, American Journal of Agricultural Economics 92, 836848.

Godard C., Roger-Estrade J., Jayet P.A., Brisson, N. and Le Bas C. (2008) Use of available information at a European level to construct crop nitrogen response curves for the regions of the EU, Agricultural Systems 97, 68-82.

Guyomard H., Le Mouël C. and Gohin A. (2004) Impacts of alternative agricultural income support schemes on multiple policy goals, European Review of Agricultural Economics 31, 125-148.

Hardaker J.B., Richardson J.W., Lien G. and Schumann K.D. (2004) Stochastic efficiency analysis with risk aversion bounds: a simplified approach, The Australian Journal of Agricultural and Resource Economics 48, 253-270.

Hennessy D.A. (1998) The Production Effects of Agricultural Income Support Policies under Uncertainty, American Journal of Agricultural Economics 80, 46-57.

INRA (2007) Alimentation des bovins, ovins et caprins: Besoins des animaux - Valeurs des aliments, Versailles, Editions Quae.

Institut de l'Elevage (2008) Les systèmes bovins laitiers en France: Repères techniques et économiques, Paris, Institut de l'Elevage.

Institut de l'Elevage (2010) 2009: l'année économique viande bovine. Perspectives 2010, Dossier Economie de l'Elevage 397, 91 p.

Lambert D.K. and McCarl B.A. (1985) Risk Modeling Using Direct Solution of Nonlinear Approximations of the Utility Function, American Journal of Agricultural Economics 67, 846-852. 
Manos B., Begum M.A.A., Kamruzzaman M., Nakou I. and Papathanasiou J. (2007) Fertilizer price policy, the environment and farms behavior, Journal of Policy Modeling 29, 87-97.

Matthews K.B., Wright I.A., Buchan K., Davies D.A. and Schwarz G. (2006) Assessing the options for upland livestock systems under CAP reform: Developing and applying a livestock systems model within whole-farm systems analysis, Agricultural Systems 90, 32-61.

Moro D., Nardella M. and Sckokai P. (2005) Regional distribution of short-run, medium-run and long-run quota rents across EU-15 milk producers, Copenhagen.

Mosnier C., Ridier A., Képhaliacos C. and Carpy-Goulard F. (2009) Economic and environmental impact of the CAP mid-term review on arable crop farming in South-western France, Ecological Economics 68, 1408-1416.

OECD (2001) Decoupling: a conceptual overview, Paris, OECD Editions.

Patten L.H., Hardaker J.B. and Pannell D.J. (1988) Utility Efficient Programming for whole-farm planning, Australian Journal of Agricultural Economics 32, 88-97.

Ridier A. and Jacquet F. (2002) Decoupling direct payments and the dynamic of decisions under price risk in cattle farms, Journal of Agricultural Economics 53, 549565 .

Thornton P.K. and Herrero M. (2001) Integrated crop-livestock simulation models for scenario analysis and impact assessment, Agricultural Systems 70, 581-602.

Zuhair S.M.M., Taylor D.B. and Kramer R.A. (1992) Choice of utility function form: its effect on classification of risk preferences and the prediction of farmer decisions, Agricultural Economics 6, 333-344. 